NIST

REFERENCE

\title{
AUTOMATION OF STRAIN-GAUGE LOAD-CELL FORCE CALIBRATION
}

Kenneth W. Yee

U.S. DEPARTMENT OF COMMERCE Technology Administration National Institute of Standards and Technology

Manufacturing Engineering Laboratory Automated Production Technology Division Gaithersburg, MD 20899 
|

, ,

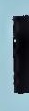

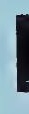




\section{AUTOMATION OF STRAIN-GAUGE LOAD-CELL FORCE CALIBRATION}

Kenneth W. Yee

U.S. DEPARTMENT OF COMMERCE

Technology Administration National Institute of Standards and Technology

Manufacturing Engineering Laboratory Automated Production Technology Division Gaithersburg, MD 20899

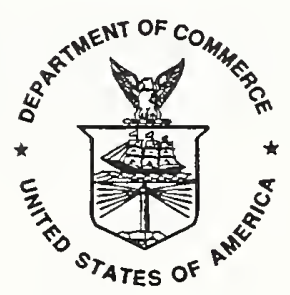

U.S. DEPARTMENT OF COMMERCE Barbara Hackman Franklin, Secretary

TECHNOLOGY ADMINISTRATION

Robert M. White, Under Secretary for Technology

NATIONAL INSTITUTE OF STANDARDS

AND TECHNOLOGY

John W. Lyons, Director 


\section{INTRODUCTION}

This paper might have been entitled "How to Make 25-Year Old Meganewtons Move by Themselves!" The six NIST dead-weight force machines with nominal capacities of $2.2 \mathrm{kN}$ (500 lbf), $27 \mathrm{kN}$ (6.1 klbf), $113 \mathrm{kN}$ (25.3 klbf), $498 \mathrm{kN}$ (112 klbf), $1.33 \mathrm{MN}$ (300 klbf), and 4.45 MN ( $1 \mathrm{Mlbf}$ ) were designed ca. 1960 and put in service in one of the first buildings at the Gaithersburg, MD site [1]. The weights ${ }^{1}$ are among the "best in the world," all stainless steel, with the mass adjusted for nominal force increments within 5 parts per million (ppm). This requires about $730 \mathrm{ppm}$ "more mass" to compensate for air buoyancy and force of gravity at the NIST site. The "machinery" and controls are, of course, consistent with the era. Large electric motors, hydraulic pumps and pistons run by relays and mechanical switches in response to an operator closing a switch. Automation required flexibility and ingenuity. Modern, precision measurements were to be incorporated. Reliability was a high priority. The task was complicated by the fact that no two machine designs are alike.

The three largest machines are similar, with sequential pick-up of weights. In the $4.4 \mathrm{MN}$ machine (the only one of this capacity in the world shown in figure 1), a hydraulic jack in the attic four-stories above, raises a lifting frame. For each incremental vertical movement of about $42 \mathrm{~mm}$, the loading frame or a weight is lifted, adding $222.4111 \mathrm{kN}$ of force to the load. There are 20 incremental weights of the same value. The device under test, e.g., a load cell, may be in tension or compression. The 1.334-MN machine is similar except that the loading frame $(44.48222 \mathrm{kN}$ [10 klbf]) and weights (also $88.96444 \mathrm{kN}$ [20 klbf] and $133.4467 \mathrm{kN}$ [30 klbf]) are of three sizes. The $498-\mathrm{kN}$ machine is also similar, but has two independent weight stacks, one of which has ten steps of $44.48222 \mathrm{kN}$ and one has nine steps of $4.4482222 \mathrm{kN}$ (1 klbf) as shown in figure 2.

The three smaller machine are very different from the large ones. Each has independently loadable weights. The lifting frames are raised by electric motors. The $27-\mathrm{kN}$ machine, shown in figure 3, has not been automated. In the $113-\mathrm{kN}$ machine, the "unused" weights are lifted from the loading shaft by two coil springs, one on each side. To load a weight, a small hydraulic piston inside each coil, compresses the spring to lower that weight onto a cone on the shaft. The pistons are controlled by electrically actuated hydraulic valves. In the 2.2-kN machine the individual weights are lifted from the loading shaft by pneumatic pistons, also controlled by electrical valves.

\footnotetext{
'Weight is used only to refer to a piece of stainless-steel metal, i.e., an object. It has a mass in kilograms, which for a given local acceleration of gravity and relative densities of air and stainless steel, produces a force in newtons.
} 


\section{AUTOMATION OF THE APPLICATION OF FORCE}

Each machine is equipped with a PC-XT computer and printer, and a data acquisition and control (DAC) unit [2] as shown in figure 4. The DAC has a 5-1/2 digit digital voltmeter (DVM) and card slots that may be filled with multiplexer relays for the voltmeter, relays to control external devices, parallel digital inputs (bits), or multiplexer relays with thermocouple reference cold junction. The selection depends on the particular machine. All digital inputs and outputs are isolated by either mechanical relays or optical isolators. The PC sends commands to the DAC and receives data back on an IEEE-488 instrumentation bus. The printer, which provides backup documentation, is connected to a parallel printer port.

A relay in the DAC is connected across each switch on the DWM's operator console that needs to be actuated to control the movement of the weights. For the three largest machines, this is just "load" and "unload," directing the hydraulic jack to raise or lower the lifting frame. The load, which determines the force on the load cell under calibration, is a function of the vertical position of the frame. The existing readout on the console is a selsyn-like receiver. A chain attached to the frame passes over a gear on the selsyn transmitter shaft with a mass on the other end of the chain. Thus, vertical motion is translated to rotational motion. The receiver shaft runs a dial pointer on the console to display the load. We attached a servo potentiometer to the transmitter shaft to produce a voltage output as a function of frame position. This voltage is read by the DVM in the DAC. The PC has a look-up table of voltage for each weight step. Actually, this table has four voltages which define two bands for each step . The inner band is the acceptable-position range for a measurement at that load. The outer "approach" band tells the machine to stop moving, as soon as the band is entered, to compensate for "coasting." The PC will readjust the machine position if it should stop outside the inner band. The $498 \mathrm{kN}$ machine has an additional voltage output and look-up table for the small weight stack which is raised and lowered by an electric motor and has additional "load" and "unload" switches.

The 113-kN and 2.2-kN DWMs are a bit more complicated to control. Both have independent weights that can be added randomly to the loading frame mass to determine the force on the load cell. In the 113-kN DWM the loading frame produces $1.779289 \mathrm{kN} \mathrm{(400} \mathrm{lbf),} \mathrm{and} \mathrm{there} \mathrm{are} 11$ individual weights (from $444.8222 \mathrm{~N}$ [100 lbf] to $22.24111 \mathrm{kN}$ [5 klbf]), each with a "load" and an "unload" switch and indicator light. Each of these switches activates one of the hydraulic valves to lower (or raise) a weight on the shaft. These valves are operated by $120 \mathrm{~V} \mathrm{ac}$ solenoids. To avoid any problems from this voltage level, all switches are paralleled by an optically isolated solid-state relay. This is conservative, but expensive. To ensure that a measurement is never taken with the incorrect force on the load cell, the voltages to the load and unload lights, which are actuated by limit switches when the weight is "in position," are sensed by digital inputs to the DAC. The computer checks the entire weight stack to verify that the programmed weights are in fact loaded. If any error is found, a command to correct it is issued. Only after verification of the loading force will a measurement cycle be started. The position of the loading frame is sensed by an optical sensor that indicates whether it is up (loads the cell) or down. 
The 2.2-kN machine is essentially the same except that it has a loading frame of $44.48222 \mathrm{~N}$ $(10 \mathrm{lbf})$ and eight weights from $22.24111 \mathrm{~N}(10 \mathrm{lbf})$ to $889.6444 \mathrm{~N}$ (200 lbf). Somewhat fewer switches are required and signals from limit switches similarly validate the loading.

\section{AUTOMATING THE MEASUREMENT}

Strain-gauge load cells are four-arm bridges, usually with $350 \Omega$ or $1 \mathrm{k} \Omega$ gauges. The bridge excitation is commonly $10 \mathrm{~V} \mathrm{dc}$. The output is expressed as a ratio. At full-scale load, the output is typically $2 \mathrm{mV} / \mathrm{V}$ or $3 \mathrm{mV} / \mathrm{V}$, i.e., one part in 500 of the excitation or one part in 333 of the excitation. Therefore, for high-precision calibrations, a ratio measurement is made. We use an 8-1/2 digit digital voltmeter [3], in ratio mode, which has an error limit specification for this measurement of $35 \mathrm{ppm}$ for a year from calibration. This DVM also communicates with the PC by the IEEE-488 bus.

The force calibrations at NIST are issued with a stated $20 \mathrm{ppm}$ uncertainty in the force values and an additional $50 \mathrm{ppm}$ or $33 \mathrm{ppm}$ uncertainty for the readout instrumentation, i.e., the DVM. The designs ${ }^{2}$ of currently available DVMs in this class assure high linearity of a given measurement range. The ratio accuracy can be significantly improved by calibration. Absolute ratio calibration at the few millivolt per volt level at the NIST Electricity Division, using a $10-\mathrm{V}$ Josephson-junction voltage array, has shown that these DVMs have linearity in the ratio mode of $3 \mathrm{ppm}$ or better. Therefore, a single-point ratio calibration at full scale of the range used $(100 \mathrm{mV}), 100: 1$ ratio, can reduce the measurement uncertainty by a factor of ten. We use a self-calibrating 100:1 ratio divider which has an uncertainty of $0.5 \mathrm{ppm}$ for this calibration. A factor is thus derived to correct the scale calibration errors in the DVM and approach the linearity limit. This calibration factor for the DVM in use, e.g., 0.999990 , is read from a file in the PC and recorded with the measurement data. It is subsequently applied to all data points by the analysis program.

Additional procedures have been incorporated to ensure the highest-precision measurements possible. After the PC determines that the DWM is at the programmed load value, a programmed delay allows the weights to settle. Then a programmable number of measurements are made, typically 4 to 6 . The DVM has a variable number of digits resolution $(6,7$, or 8 decimal places) with correspondingly longer measurement time for the additional digits. A sixdigit ratio measurement takes $1.2 \mathrm{~s}$, seven-digits $10 \mathrm{~s}$, and an eight-digit ratio measurement $150 \mathrm{~s}$. We find it advantageous for the computer to average the readings from several lower resolution readings rather than have the DVM average over a longer period. This way, we can calculate a standard deviation (SD) of the measurements and identify an outlier or noisy measurement caused by interference or "swinging" weights. The PC has a programmed SD

\footnotetext{
${ }^{2}$ Not all such high-precision DVMs on the market are suitable for ratio measurements of strain-gauge load-cell outputs. The signal varies from zero to $30 \mathrm{mV}$. With the typical $10 \mathrm{~V}$ dc excitation, the "reference" terminals of the DVM for the ratio measurement are $\pm 5 \mathrm{~V}$ with respect to the signal terminals. Some DVMs allow only $0.25 \mathrm{~V}$ or $0.5 \mathrm{~V}$ difference from the signal common to the reference common.
} 
limit and will automatically collect another set of data if this limit is exceeded. A SD of $0.00002 \mathrm{mV} / \mathrm{V}$ is common.

An additional option is to take a set of readings, reverse the excitation polarity, then take another set. These readings are then averaged. This procedure cancels the zero reading of the DVM and cancels the effect of thermally induced voltages in the wiring due to dissimilar metal junctions (i.e., incidental thermocouples). As an additional precaution, the $10-\mathrm{V}$ excitation power supply produces $\pm 5 \mathrm{~V}$ with respect to ground. Since the bridge output is half-way between the excitation voltage, it is near ground potential. This minimizes the effects of any leakage resistance paths in the bridge. The power supply, a NIST design, has short-term instability in the ppm range, remote sensing, and incorporates the reversing relay.

\section{USING THE CALIBRATION SYSTEM}

The majority of load-cell calibrations at NIST are based on the American Society for Testing and Materials Standard Practice E74 "Calibration of Force-Measuring Instruments for Verifying the Force Indication of Testing Machines" [4]. The load cell will commonly be preloaded to capacity 3 times, followed by 5 force steps at $20 \%$ of capacity intervals, a return to zero, then 5 additional steps offset by $10 \%$ of capacity from the first series. The cell is then manually rotated $120^{\circ}$ about its loading axis and the force steps are repeated. A third series of measurements is made after another rotation. To facilitate this procedure, the PC program has a built-in routine that can be selected to perform the preload. The force steps can be read from a file or entered from the keyboard. At start-up, the number of readings, number of DVM digits, and choice of voltage reversal between measurements are selected. The data file is in a format which is directly read by the NIST analysis program which produces the NIST Report of Force Calibration. Due to the manual rotation of the cell, only portions of a force calibration run unattended.

\section{NTEP/OIML CONFORMANCE TESTING}

The National Conference of Weights and Measures (NCWM), National Type Evaluation Program (NTEP) specifies the tolerances and test procedures for load cells used as weighing elements in scales used in commerce [5]. NTEP specifications are based on a recommendation,

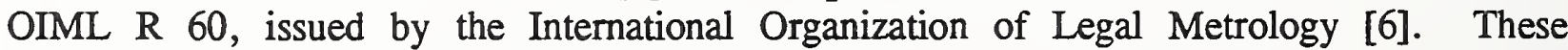
specifications require testing at a minimum of five load steps to capacity and back to "zero" at $20^{\circ} \mathrm{C},-10^{\circ} \mathrm{C}, 40^{\circ} \mathrm{C}$ and again at $20^{\circ} \mathrm{C}$, with three runs at each temperature. Additionally, a creep test must be performed at each temperature where the cell is loaded to capacity and the variation in output monitored for one hour. This is obviously time consuming, particularly for temperature equalization of larger cells with considerable thermal mass.

To implement these conformance tests, a temperature chamber (shown in figure 4) is added to the DWM test space. The load is applied to the cell through an opening in the top of the chamber. Our chambers are conditioned by circulating liquid from an external bath with a programmable temperature setting. The PC programs the bath through an RS-232C serial 
(COM1) port. Thermocouples (TCs) attached to the cell are read by the DVM in the DAC. The PC converts the TC-voltage readings to temperature with a polynomial. A thermalequilibrium criterion is used based on readings from multiple TCs in the chamber. After a programmed additional soak time, the force steps are automatically applied and the cell output measured and recorded. After the test cycle at one temperature, the bath is automatically set to the next test temperature and the temperatures monitored for equilibrium. After a soak period, the tests at the second temperature are started. This continues for the four test temperatures. For nearly four years, these NTEP-type-evaluation tests have run unattended, 24 hours a day, frequently over the weekend. A cell evaluation may take up to 2-1/2 days to complete. Clearly, the savings from automation are invaluable.

\section{ACKNOWLEDGMENTS}

This paper is dedicated in memory of Clara Bird who wrote much of the initial software. The weights would not move without the software also by C. Amoruso and T. Bartel; the hardware by M. Hahn, E. Reisenauer, C. Shoemaker and S. Ho; and D. Blomquist who said "The weights shall move!"

\section{REFERENCES}

1. Mitchell, Richard A., "Force Calibration at the National Bureau of Standards," NBS Technical Note 1227, National Bureau of Standards, Gaithersburg Maryland, August 1986.

2. "Operating, Programming and Configuration Manual Model 3497A, Data Acquisition/Control Unit," Hewlett-Packard Co., Loveland Colorado, 1982.

3. "7081 Precision Digital Voltmeter Operating Manual," Solartron Instruments, Schlumberger Electronics Ltd., Hampshire, England, 1983.

4. "Standard Practice of Calibration of Force-Measuring Instruments for Verifying the Force Indication of Testing Machines," E 74-91, Annual Book of ASTM Standards, American Society for Testing and Materials, Philadelphia PA, April 1991.

5. "Administrative Procedures, Technical Policy, Checklists, and Test Procedures," NCWM Publication 14, 2nd Edition, National Institute of Standards and Technology, Gaithersburg MD, January 1989.

6. "Metrological regulation for load cells," OIML R60, Organisation Internationale de Metrology Legale, Troyes, France, 1991. 
Jack Room Floor

Hydraulic Jack

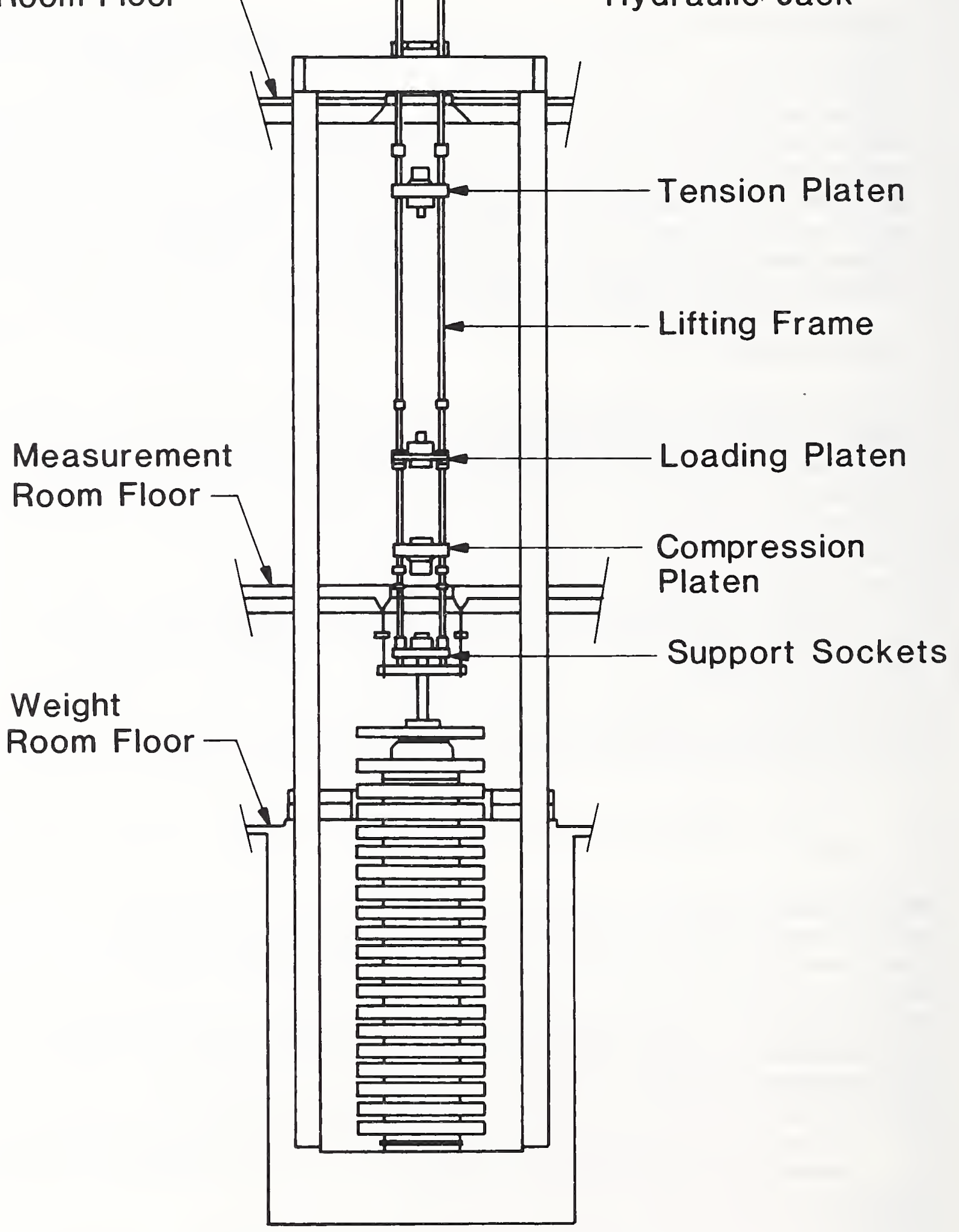

Figure 1. The 4.4-MN dead-weight machine 


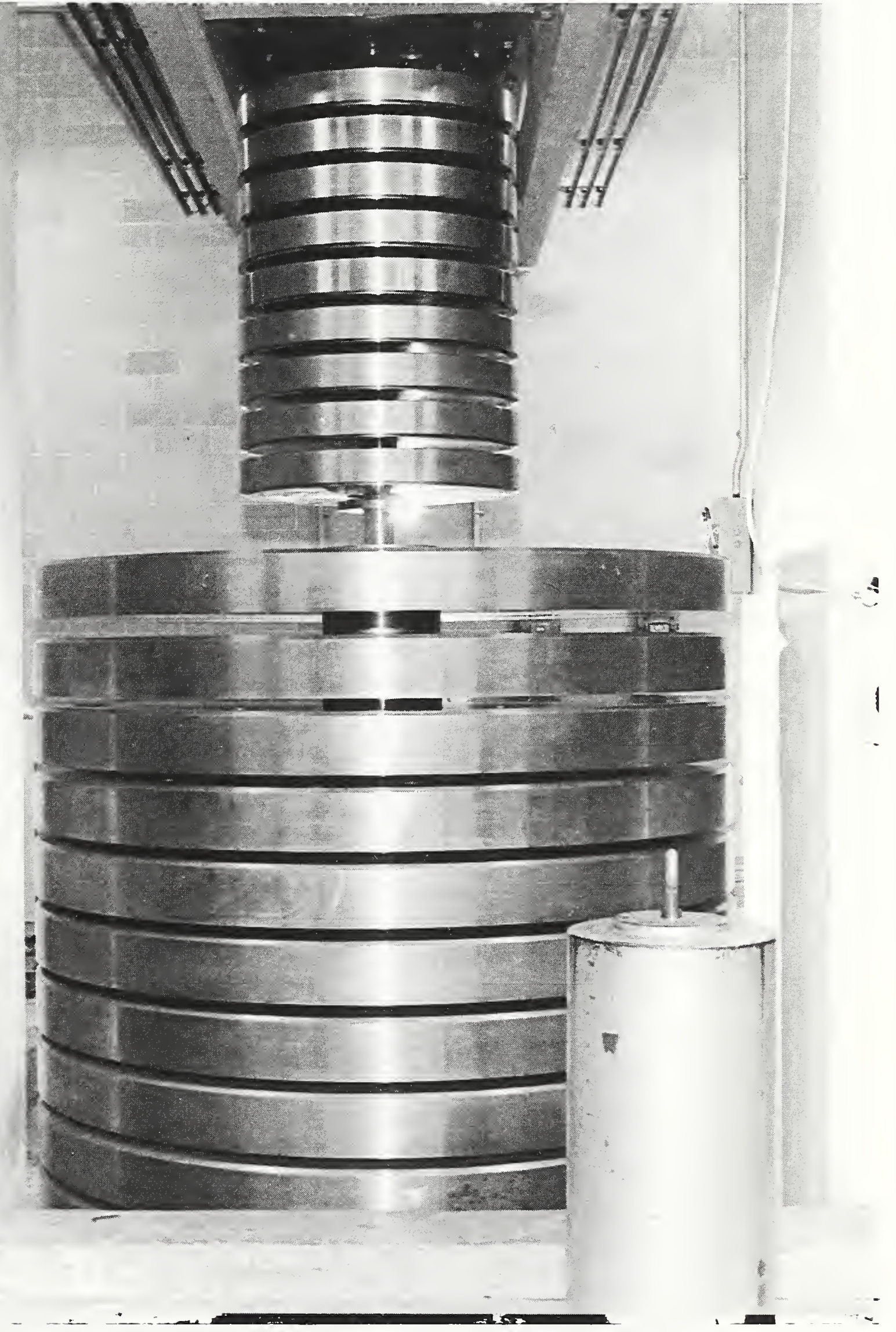

Figure 2. The two weight stacks of the 498-kN dead-weight machine 


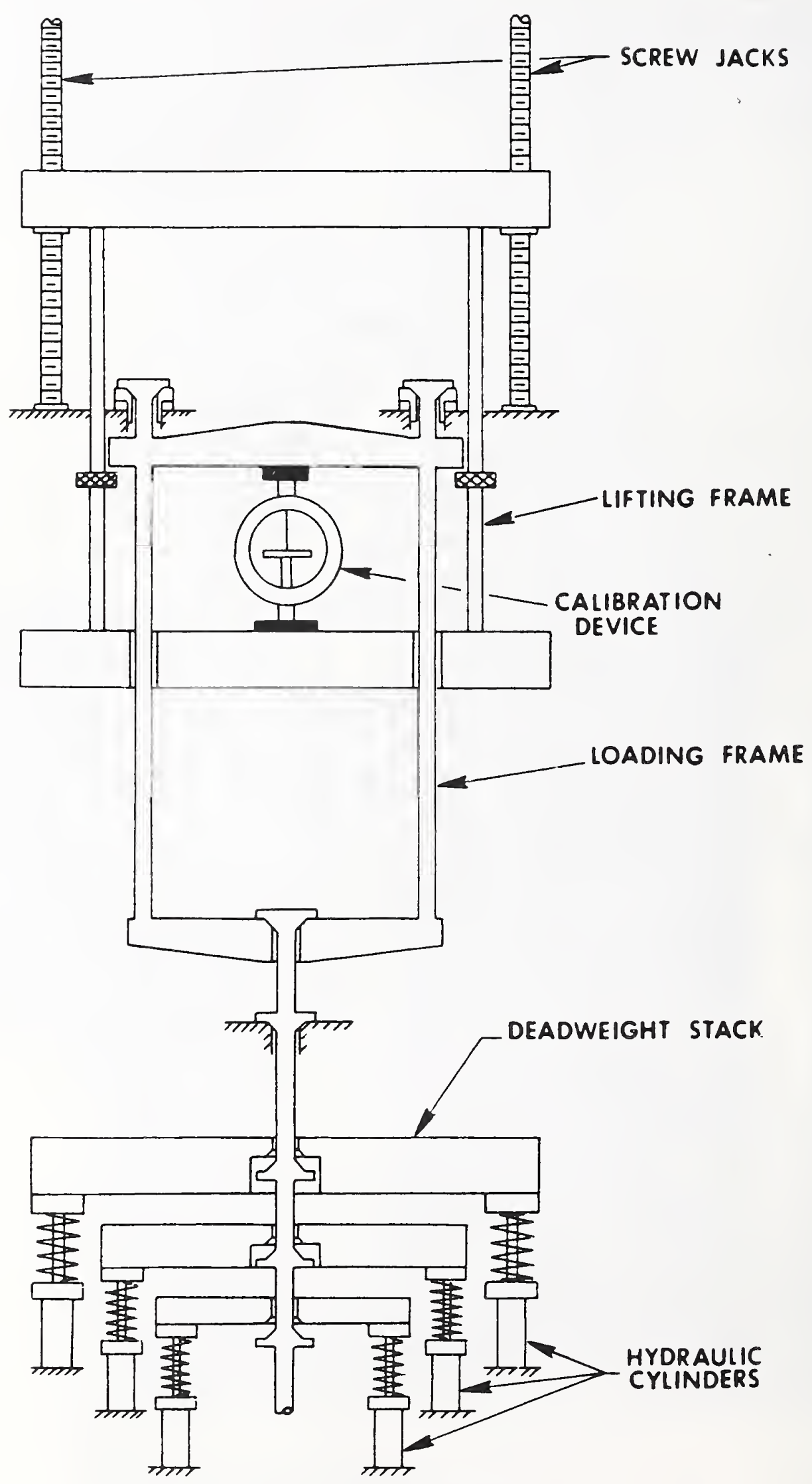

Figure 3. The 27-kN dead-weight machine (similar to the 113-kN machine) 



\begin{tabular}{|r}
\hline $\begin{array}{l}\text { NIST-114A } \\
\text { (REV. 3-90) }\end{array}$ \\
NATIONAL INSTITUTE OF STANDARDS AND TECHNOLOGY \\
BIBLIOGRAPHIC DATA SHEET
\end{tabular}

4. TITLE AND SUBTITLE

Automation of Strain-Gauge Load-cell Force Calibrations

5. AUTHOR(S)

Kenneth $W$. Yee

6. PERFORMING ORGANIZATION (IF JOINT OR OTHER THAN NIST, SEE INSTRUCTIONS)

U.S. DEPARTMENT OF COMMERCE

MATIONAL INSTITUTE OF STANDARDS AND TECHNOLOGY

GATTHERSBURG, MD 20899

9. SPONSORING ORGANIZATION MAME AND COMPLETE ADDRESS (STREET, CITY, STATE, ZIP)
7. CONTRACT/GRANT NUMBER

8. TYPE OF REPORT AND PERIOD COVERED

\section{SUPPLEMENTARY MOTES}

11. ABSTRACT (A 200-WORD OR LESS FACTUAL SUMMARY OF MOST SIGNIFICANT INFORMATION. IF DOCUMENT INCLUDES A SIGNIFICANT BIBLOGRAPHY OA UTERATURE SURVEY, MENTION IT HERE.)

The National Institute of Standards and Technology (NIST) has six dead-weight machines (DWMs), used for force calibrations up to 4.4 meganewtons (MN), which were all placed in service ca. 1965. More than 20 years later, five of these machines were automated. They now automatically apply programmed force vaiues to the strain-gauge load cell and record the output using a high-precision digital voltmeter, all controlled by a PC-XT class computer. Subsequently, environmental chambers have been added to three machines to perform automatically the type evaluation testing of load cells used in scales in commerce.

12. KEY WORDS (6 TO 12 ENTRIES; ALPHABETICAL ORDER; CAPITALIZ ONLY PROPER NAMES; AND SEPARATE KEY WORDS BY SEMICOLONS)

automation; calibration; dead weight; force; load cell; newton; strain gauge

13. AVAILABIUT'Y

\section{$\mathrm{X}$ UNUMITED}

FOR OFFICIAL DISTRIBUTION. DO NOT RELEASE TO NATIONAL TECHNICAL INFORMATION SERVICE (NTIS).

ORDER FROM SUPERINTENDENT OF DOCUMENTS, U.S. GOVERNMENT PRINTING OFFICE, WASHINGTON, DC 20402.

ORDER FROM NATIONAL TECHNICAL INFORMATION SERVICE (NTIS), SPRINGFIELD, VA 22161.
14. NUMBER OF PRINTED PAGES

12

15. PAICE

$\mathrm{AO} 2$ 


\section{•}



